\title{
Markers of JC virus infection in patients with multiple sclerosis under natalizumab therapy
}

\section{OPEN}

Valeria Clausi, $\mathrm{PhD} *$

Simone Giannecchini, $\mathrm{PhD}^{*}$

Eliana Magnani, MD Anna Repice, MD

Claudia Mechi, MD

Francesco Martelli,

MbiolSc

Alberta Azzi, PhD

Luca Massacesi, MD

Correspondence to

Dr. Giannecchini:

simone.giannecchini@unifi.it

\section{ABSTRACT}

Objective: To evaluate the frequency of JC polyomavirus (JCPyV) infection and anti-JCPyV antibodies in patients with multiple sclerosis under natalizumab therapy.

Methods: Presence of anti-JCPyV antibodies and JCPyV DNA was analyzed in 39 patients with relapsing-remitting multiple sclerosis undergoing natalizumab therapy. Anti-JCPy antibodies were evaluated in serum by a 2-step virus-like particle-based ELISA assay (Stratify), and JCPyV DNA was evaluated in peripheral blood mononuclear cells, plasma, and urine by quantitative PCR. The anti-JCPyV antibodies were evaluated in serum samples collected at the same time or later than those collected for DNA analysis.

Results: JCPy $V$ DNA was detected in 59\% of patients, and anti-JCPy $V$ antibodies were present in $67 \%$. JCPYV DNA occurred more often in blood than in urine. Anti-JCPyV antibodies were observed in $70 \%$ of the JCPyV-infected patients, and JCPyV DNA was detected in 50\% of the patients without anti-JCPYV antibodies. When JCPyV DNA was investigated in blood and urine the frequency of infection was higher than previously described.

Conclusion: Under these experimental conditions, with respect to the observed frequency of JCPyV infection, the sensitivity of the anti-JCPyV antibody assay was lower than expected. Neurol Neuroimmunol Neuroinflamm 2015;2:e58; doi: 10.1212/NXI.0000000000000058

\section{GLOSSARY}

$\mathbf{A b}=$ antibody; $\mathbf{J C P y V}=\mathrm{JC}$ polyomavirus; $\mathbf{M A H}=$ Marketing Authorization Holder; $\mathbf{M S}=$ multiple sclerosis; $\mathbf{P B M C}=$ peripheral blood mononuclear cells; $\mathbf{P M L}$ = progressive multifocal leukoencephalopathy; RRMS = relapsing-remitting multiple sclerosis.

Progressive multifocal leukoencephalopathy (PML) caused by JC polyomavirus (JCPyV) reactivation is the most severe adverse event observed in patients with relapsing-remitting multiple sclerosis (RRMS) treated with natalizumab. ${ }^{1}$ In order to predict PML risk, a biological marker of JCPyV infection is needed. Because of the intermittent nature of JCPyV productive infection and because JCPyV DNA detection by PCR assay may be elusive, the presence of anti-JCPyV antibodies (Abs) seems to be a marker of infection that is more stable over time. Based on this assumption, an assay that is highly sensitive and specific for the detection of anti-JCPyV Abs in serum (Stratify) was developed. ${ }^{2}$ In addition, an algorithm based on this assay has been developed and validated for PML risk stratification in patients with multiple sclerosis (MS) treated with natalizumab. ${ }^{3}$ However, the actual frequency of JCPyV-infected patients in MS patient populations is still controversial, mainly because it depends on the JCPyV DNA identification method. Here the sensitivity of the Stratify test in patients with MS was evaluated by comparing the frequency of anti-JCPyV Abs with the frequency of JCPyV DNA in different body fluid compartments.

METHODS Patients. Paired blood and urine samples from 39 patients who were consecutively referred to the outpatient clinic of the Regional Reference Center for Multiple Sclerosis of the Careggi University Hospital, Florence, Italy, were prospectively collected.

\footnotetext{
*These authors contributed equally to the work.

From the Department of Experimental and Clinical Medicine (V.C., S.G., F.M., A.A.) and Department of Neurosciences, Drugs and Child Health (E.M., L.M.), University of Florence; and Neurology 2 Division (A.R., C.M., L.M.), Careggi University Hospital, Florence, Italy.

Go to Neurology.org/nn for full disclosures. Funding information and disclosures deemed relevant by the authors, if any, are provided at the end of the article. The Article Processing Charge was paid by the Department of Experimental and Clinical Medicine, University of Florence.

This is an open access article distributed under the terms of the Creative Commons Attribution-Noncommercial No Derivative 3.0 License, which permits downloading and sharing the work provided it is properly cited. The work cannot be changed in any way or used commercially.
} 


\begin{tabular}{|c|c|c|c|c|}
\hline \multirow[t]{2}{*}{ Table 1} & \multicolumn{4}{|c|}{$\begin{array}{l}\text { Baseline demographic and clinical characteristics of the patients } \\
\text { according to JCPyV status }\end{array}$} \\
\hline & & All patients & $\begin{array}{l}\text { JCPyV DNA } \\
\text { positive }\end{array}$ & $\begin{array}{l}\text { JCPyV DNA } \\
\text { negative }\end{array}$ \\
\hline Total no. & & 39 & 23 & 16 \\
\hline Sex, F:M & & $30: 9$ & $18: 5$ & $12: 4$ \\
\hline \multicolumn{5}{|l|}{ Age } \\
\hline \multicolumn{2}{|c|}{ Mean $\pm S D, y$} & $37.8 \pm 9.2$ & $35.9 \pm 7.9$ & $40 \pm 10.1$ \\
\hline \multicolumn{2}{|c|}{ Median, y } & 38 & 33 & 39.5 \\
\hline \multicolumn{5}{|c|}{ Disease duration } \\
\hline \multicolumn{2}{|c|}{ Mean $\pm S D, y$} & $11.6 \pm 5.8$ & $11.1 \pm 5.0$ & $12.2 \pm 6.5$ \\
\hline \multicolumn{2}{|c|}{ Median, y } & 10 & 10 & 10.5 \\
\hline \multicolumn{5}{|c|}{ Previous treatments, $\mathrm{n}$} \\
\hline \multicolumn{2}{|l|}{ IFN- $\beta$} & 37 & 21 & 16 \\
\hline \multicolumn{2}{|c|}{ Copolymer } & 9 & 6 & 3 \\
\hline \multicolumn{2}{|c|}{ Azathioprine } & 19 & 11 & 8 \\
\hline \multicolumn{2}{|c|}{ Mitoxantrone/cyclophosphamide } & 4 & 3 & 3 \\
\hline
\end{tabular}

Abbreviations: IFN = interferon; JCPyV = JC polyomavirus.

The patients were recruited according to the following inclusion criteria: definite diagnosis of MS; relapsing-remitting course; fulfillment of the European Medicines Agency indications for natalizumab administration in MS; and written informed consent to participate in a program for PML risk stratification established in collaboration with the Marketing Authorization Holder (MAH) of natalizumab and based on a centralized antiJCPyV Ab assay in sera and on a locally organized JCPyV DNA analysis in blood and urine. The results included in the present study were generated by analyzing the diagnostic data reported in the clinical records. The study was approved by the local Ethic Committee (Comitato Etico Azienda OspedalieroUniversitaria Careggi, Largo Brambilla 3, Firenze) according to the Italian law requirements (n. OSS 14.073). The authors obtained preventive unrestricted permission for analyzing the data provided by the MAH of the anti-JCPyV Ab assay.

JCPyV PCR quantification. The JCPyV DNA was extracted from peripheral blood mononuclear cells (PBMC) obtained from enriched buffy coats after density gradient separation of $8 \mathrm{~mL}$ of whole blood, $200 \mu \mathrm{L}$ of plasma, and $200 \mu \mathrm{L}$ of urine, and was quantified by JCPyV-specific real-time PCR targeting the large T gene performed in triplicate using $100 \mathrm{ng}$ of DNA (forward primer 5'-GCAGCTTAGTGATTTTCTTAGG-3', reverse primer 5'GAACACAGGTGTTTCCACCTGG-3', and TaqMan MGB probe Fam-5'-GGCACTGAATATTCATTCATGG3'). Each assay was carried out with negative controls (no template) and DNA 10 -fold dilutions $\left(10^{1}-10^{6}\right.$ copies) of a plasmid carrying the amplicon cloned (standard curve plot was $10^{1}-10^{6}$ copies vs 36-21 cycle threshold). The lower limit of quantification of the JCPyV DNA was 100 copies per $\mathrm{mL}$ of plasma and urine or per $\mu \mathrm{g}$ of PBMC DNA.

JCPyV antibody assay. Anti-JCPyV Abs were detected in serum by a 2-step virus-like particle-based ELISA assay (Stratify, Focus Diagnostics, provided by Biogen Idec). ${ }^{4}$ Patients who tested positive for JCPyV DNA in blood or urine but who had undetectable serum antibodies had their serum samples retested for anti-JCPyV Abs.

RESULTS Demographic and clinical characteristics and JCPyV infection status of the 39 patients with RRMS are reported in table 1. The blood and urine samples were collected biannually at baseline and during the therapy, from July 2008 to September 2012. Patients received between 0 and 35 infusions and contributed between 1 and 8 samples. We included in the study the first positive isolation of JCPyV DNA and the anti-JCPyV $\mathrm{Ab}$ assay evaluated in the serum sample of the same patient collected concurrently or after the JCPyV DNA isolation. Eleven out of 39 samples included were collected at baseline, and the other 28 were collected during natalizumab administration. No obvious associations between patient demographic and clinical characteristics (age, sex, disease duration, previous treatments) and $\mathrm{JCPyV}$ DNA status were observed. Overall, JCPyV DNA was detected in at least one body fluid in 23 of 39 patients (59\%; table 2 and table e- 1 at Neurology.org/nn): 17 patients (44\%) had JCPyV DNA in PBMC, 4 patients $(10 \%)$ in plasma, and 13 patients $(33 \%)$ in urine (table 2). Of note, the assay could detect JCPyV

\begin{tabular}{|c|c|c|c|c|c|c|}
\hline Table 2 & NA and an & :-JCPyV A & b status in & the patients with & RRMS included in & he study \\
\hline & Positive & Negative & Total & Urine (copies/mL) & Plasma (copies $/ \mathrm{mL}$ ) & 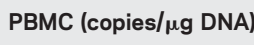 \\
\hline \multirow[t]{2}{*}{ JCPyV DNA status ${ }^{a}$} & 23 (59\%) & $16(41 \%)$ & 39 & 13 (33\%) & 4 (10\%) & 17 (44\%) \\
\hline & & & & $2 \times 10^{2}-3 \times 10^{4}$ & $6 \times 10^{2}-8 \times 10^{3}$ & $2 \times 10^{2}-7 \times 10^{3}$ \\
\hline \multicolumn{7}{|l|}{ Anti-JCPyV Ab } \\
\hline Positive & 16 & 9 & 25 (64\%) & & & \\
\hline Negative & 7 & 7 & 14 (36\%) & & & \\
\hline
\end{tabular}

Abbreviations: $\mathrm{Ab}=$ antibody; JCPyV = JC polyomavirus; $\mathrm{PBMC}=$ peripheral blood mononuclear cells; RRMS = relapsingremitting multiple sclerosis.

${ }^{a}$ The numbers represent the patients who tested positive for JCPyV DNA and/or for anti-JCPyV Ab presence. The range of copy numbers obtained in urine, plasma, and PBMCs are also reported. The samples were collected every 6 months during natalizumab therapy (from 0 to 38 infusions).

For the anti-JCPyV Ab assay, we used only the serum samples obtained at the same time or after those from the first JCPyV DNA analysis that tested positive. 
DNA in 1 of $20(5 \%)$ blood (PBMC or plasma) samples and in 11 of $20(55 \%)$ urine samples of healthy donors. The range of viral load was similar in the different compartments (table 2).

Anti-JCPyV Abs were present in 25 of 39 patients included (64\%) and in 16 of the $23 \mathrm{JCPyV}$-infected patients (70\%; table 2 and table e- 1 ), indicating an assay sensitivity of 0.7 . In addition, JCPyV DNA was present in 7 of the 14 anti-JCPyV antibody-negative patients (50\%; table 2$)$, indicating that the negative predictive value of the assay was 0.5 . However, in this context, the viral load observed in seronegative patients did not differ from that observed in the seropositive patients. Of note, only 1 of the 7 patients who was anti-JCPyV Ab-negative despite the presence of JCPyV DNA in PBMC showed seroconversion in a sample taken within 6 months.

DISCUSSION In the present study, the frequency of JCPyV DNA (59\%) in patients with MS treated with natalizumab was higher than that previously reported when JCPyV infection was evaluated only in urine $(24 \%)^{2,5}$ and was consistent with that reported when the infection was evaluated in PBMC (60\%). ${ }^{6}$

The high frequency of JCPyV in PBMC, a cell compartment well-known for its ability to harbor JCPyV-DNA, was not unexpected, particularly in patients treated with natalizumab, considering the effects of this drug on lymphoid precursor cells. ${ }^{7}$

The frequency of anti-JCPyV Abs observed in serum (64\%) was consistent with previous observations in similar populations. ${ }^{4,8}$ However, in our study, anti-JCPyV Abs were present in only $70 \%$ of the 23 patients with JCPyV infection. This result puts the sensitivity of the Stratify test at $70 \%$, whereas in previous studies that used the same assay to detect antiJCPyV Abs sensitivity was reported to be $97 \%{ }^{4,9}$ This difference should probably be attributed to the method of identifying the presence of the JCPyV DNA, as the serologic data reported here and in previous studies ${ }^{2,4}$ have been obtained with the same methods (the Stratify test). The previous data have been obtained by testing the virus DNA only in urine, whereas more recent data and the present study indicate that when peripheral blood is also tested the frequency of JCPyV DNA is higher than previously described, particularly during natalizumab treatment. ${ }^{79}$ In addition, the present study data, which put the negative predictive value of the Ab assay at $50 \%$, are consistent with other recent observations reporting that when peripheral blood was included in the analysis the false-negative rate of JCPyV serology was $37 \%{ }^{10}$ and $35 \% .{ }^{9}$

The present results indicate that JCPyV DNA evaluation in blood and urine could detect JC virus infection earlier than anti-JCPyV Ab serology. Thus, anti-JCPyV Ab serology may underestimate JCPyV infection frequency, so it may be useful but not always sufficient to predict PML risk. This possibility points out the need to reevaluate the PML risk thus far reported in anti-JCPyV seronegative patients through additional virologic investigations. ${ }^{\mathrm{e}}{ }^{\mathrm{H}}$ However, the limited number of patients included does not allow us to conclusively quantify the real frequency of anti-JCPyV Ab-positive patients among the JCPyV-infected patients with MS. This should be reevaluated in a larger set of patients identified by assessing JCPyV DNA in paired blood and urine samples.

\section{AUTHOR CONTRIBUTIONS}

V. Clausi contributed to data collection, data analysis, and interpretation of the data. S. Giannecchini contributed to data analysis, interpretation of the data, drafting of the manuscript, and revision of the manuscript. E. Magnani contributed to patient recruitment and follow-up and interpretation of the data. A. Repice contributed to patient recruitment and follow-up and collection, analysis, and interpretation of the data. C. Mechi contributed to patient recruitment and follow-up and collection, analysis, and interpretation of the data. F. Martelli contributed to data collection and data analysis. A. Azzi contributed to interpretation of the data and drafting of the manuscript. L. Massacesi contributed to the design, interpretation of the data, and revision and supervision of the manuscript.

\section{ACKNOWLEDGMENT}

The authors thank Biogen Idec for the Stratify test assays.

\section{STUDY FUNDING}

The work was supported by grants from the Fondazione "Istituto di Ricerca Virologica Oretta Bartolomei Corsi” Florence, Italy.

\section{DISCLOSURE}

V. Clausi, S. Giannecchini, E. Magnani, A. Repice, C. Mechi, F. Martelli, and A. Azzi report no disclosures. L. Massacesi received reimbursements for meeting participation or educational grants from Biogen Idec, MerckSerono, Sanofi-Aventis, and Novartis. L. Massacesi is a member of the Scientific Advisory Group (SAG) Neurology of the European Medicines Agency (EMA) and of the Italian Medicines Agency (Agenzia Italiana del Farmaco, AIFA), but the opinions included in this article may not represent the positions of these agencies. Go to Neurology.org/nn for full disclosures.

Received May 14, 2014. Accepted in final form December 1, 2014.

\section{REFERENCES}

1. Sørensen PS, Bertolotto A, Edan G, et al. Risk stratification for progressive multifocal leukoencephalopathy in patients treated with natalizumab. Mult Scler 2012;18: 143-152.

2. Gorelik L, Lerner M, Bixler S, et al. Anti-JC virus antibodies: implications for PML risk stratification. Ann Neurol 2010;68:295-303.

3. Bloomgren G, Richman S, Hotermans C, et al. Risk of natalizumab-associated progressive multifocal leukoencephalopathy. N Engl J Med 2012;366:1870-1880.

4. Bozic C, Richman S, Plavina T, et al. Anti-John Cunnigham virus antibody prevalence in multiple sclerosis patients: baseline results of STRATIFY-1. Ann Neurol 2011;70:742-750. 
5. Sadiq SA, Puccio LM, Brydon EW. JCV detection in multiple sclerosis patients treated with natalizumab. J Neurol 2010;257:954-958.

6. Chen Y, Bord E, Tompkins T, et al. Asymptomatic reactivation of JC virus in patients treated with natalizumab. $\mathrm{N}$ Engl J Med 2009;361:1067-1074.

7. Skarica M, Eckstein C, Whartenby KA, Calabresi PA. Novel mechanisms of immune modulation of natalizumab in multiple sclerosis patients. J Neuroimmunol 2011;235:70-76.
8. Olsson T, Achiron A, Alfredsson L, et al. Anti-JC virus antibody prevalence in a multinational multiple sclerosis cohort. Mult Scler 2013;19:1533-1538.

9. Major EO, Frohman E, Douek D. JC viremia in natalizumab-treated patients with multiple sclerosis. N Engl J Med 2013;368:2240-2241.

10. Berger JR, Houff SA, Gurwell J, Vega N, Miller CS, Danaher RJ. JC virus antibody status underestimates infection rates. Ann Neurol 2013;74:84-90. 


\title{
Neurology $^{\odot}$ \\ Neuroimmunology \& Neuroinflammation
}

\author{
Markers of JC virus infection in patients with multiple sclerosis under natalizumab \\ therapy \\ Valeria Clausi, Simone Giannecchini, Eliana Magnani, et al. \\ Neurol Neuroimmunol Neuroinflamm 2015;2; \\ DOI 10.1212/NXI.0000000000000058
}

This information is current as of January 14, 2015

Updated Information \&

Services

Supplementary Material

References

Subspecialty Collections

Permissions \& Licensing

Reprints including high resolution figures, can be found at:

http://nn.neurology.org/content/2/1/e58.full.html

Supplementary material can be found at:

http://nn.neurology.org/content/suppl/2015/01/14/2.1.e58.DC1

This article cites 10 articles, 0 of which you can access for free at: http://nn.neurology.org/content/2/1/e58.full.html\#\#ref-list-1

This article, along with others on similar topics, appears in the following collection(s):

Multiple sclerosis

http://nn.neurology.org//cgi/collection/multiple_sclerosis

Information about reproducing this article in parts (figures,tables) or in its entirety can be found online at:

http://nn.neurology.org/misc/about.xhtml\#permissions

Information about ordering reprints can be found online:

http://nn.neurology.org/misc/addir.xhtml\#reprintsus

Neurol Neuroimmunol Neuroinflamm is an official journal of the American Academy of Neurology.

Published since April 2014, it is an open-access, online-only, continuous publication journal. Copyright $(0$ 2015 American Academy of Neurology. All rights reserved. Online ISSN: 2332-7812.

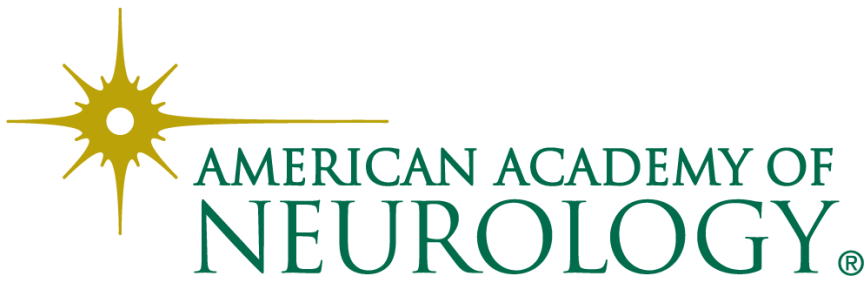

